International Journal of

Emerging Multidisciplinary Research

\title{
The Great Yuan Dynasty's Contributions to Economy and Managerial Mentality Development of Mongolia
}

\author{
Batkhurel. G ${ }^{1}$, Gunbileg. $\mathbf{T s}^{2}$ and Enkhchimeg. $\mathbf{T s}^{3}$ \\ ${ }^{1-3}$ Lecturers at Mandakh Burtgel University, Mongolia
}

\begin{abstract}
Background/Objectives: It is aimed to define what contributions the Yuan Dynasty khans put to the hist orical heritage of Mongolian Management mentality development and display policies and features of op erations to manage its economy; identify main characteristics of policies and operations applied by them to manage the economy of the royalty. Methods/Statistical analysis: The study aims to define contribut ions made by the Mongolian Yuan Dynasty to the economy of Mongolia and the historical heritage of Managerial mentality development and display policies and features of operations to manage its econom y. Findings: The research was conducted based on the historical method, historical sources and historica 1 documents. Moreover findings were revealed by comparing outcomes of studies conducted by archeolo gists from different countries such as Germany, Russia, China, India and Mongolia. Some Mongolian an $\mathrm{d}$ foreign researchers have studied features and historical heritage of Management mentality development of Mongolia that has a history of 25 centuries. However, there is not only little work done on the $\mathrm{Gr}$ eat Yuan Dynasty, but marvelous merits in economical management have not been studied yet. Improve ments/Applications: Khubilai Khaan was a founder of political science and established science academy at that time. He could improve the foreign relations on cooperation by making friendship agreement wit $\mathrm{h}$ neighbor countries.
\end{abstract}

\section{Index Terms}

Execution, Commerce, Policy, Operations, Tax, Enterprise

\section{Corresponding author : Enkhchimeg}

chimge2002@must.edu.mn

- Manuscript received January 24, 2019.

- Revised February 25, 2019 ; Accepted march 20, 2019.

- Date of publication March 31, 2019.

() The Academic Society of Convergence Science Inc.

2546-1583 $\odot 2017$ IJEMR. Personal use is permitted, but republication/redistribution requires IJEMR permission. 


\section{INTRODUCTION}

Khubilai Khan /1260/ was enthroned as king after his conquest to North China and Yuan Dynasty was existed for 108 years since its establishment in 1271 [1].

Mongolia was called in names such as "Mongolia during Yuan period", "Mongolian Yuan Dynasty" and "Great Yuan Dynasty" during the period of 12601368. Yuan Dynasty was the great empire which governs huge territory from east to west covering the area through Middle Asia from Korea and Turkistan and vertically, to Baikal Lake from Andaman, Java and Sumatran islands. So forth, rituals even including habits of life and administrative laws and legislations were dictated by Mongolians, and the leaders of the empire were descendants of Chinggis Khan and his golden generation.

Scientists considered the population of Yuan Dynasty was 62 million and comprised of 12 great states as 1 internal state and 11 foreign states. This powerful empire governed whole territory of Asia except Siberia and Japan and its governor was Mongolian Great State. So forth, law and legislation, habit of rites and rituals were Mongolian tradition and leaders of empire were descendants of Chinggis Khan and his golden generation.

During the period of Yuan Dynasty, demoded cities and settlements from middle age were destroyed under the battles, however new establishments and fortresses were built up facing to the future. Those settlements are such as Beijing, Shandu, Inzun, Bukharia, Samarkand, Tabriz, Kutlug, Andijai, Sarai of Batu, Sarai of Berkhu and so on.

Khubilai Khan established administrative and governing organizations and sectors to lead empire's state affairs. Internal literacy ministry and Treasure ministry were operated at that time. There is found historical resources that minister and vice ministers were appointed as agencies were newly established such as Science Academy in 1260, Governor's Cabinet of Livestock Affairs in 1263, Ministry of Agriculture in 1270, Internal Affairs ministry in 1284 and Ministry of Culture and Education in 1290. Also Science Academy was instituted in 1275 [2].

The ministry of Dignitary Affairs, the Ministry of Rituals, the Military Ministries had been operated until the consolidation by the king's degree in 1265 . New legislations on army issues were adopted by Khubilai Khan in 1263 [3].

Internal literacy ministry was the supreme authority in role of "decision making on state and political affairs" which was found by wise minister, EliuChutsai at first. After Khubilai Khan, the system and structure of state management were transacted in more detailed form. In time of Khubilai Khan, Kharakhorum was the capital city of great empire and became center of scientists and treasures across from worldwide. Ambassadors appointed to Kharakhorum from Europe, Iran and China and traders, experts and missionaries were constantly along the way of this city. Mongolia was used the structure of ministry, commission and its form in common through the state and public management. There was a change in organization that the vice governors' power was transferred to the middle governors to keep people life peaceful and allow them to keep a steady lifestyle. For example: The governor was appointed who is in sovereign role of Shinjeu and Chinese officers Liu Su, Li Jian, Jan Hen were charged in this position.

During the period of Khaidu Khan, so called the Royal Union was established in 1266. They settled in the areas nearby Tarbagatai mountains and ruled them.

In decision of assembly, the main issue was stated that "it's not allowed to demand unfair requisitions to settled citizens". This decision was aimed to govern that area properly by pacifying those folks to conduct their livelihood activities and to create peaceful relation with them.

There is a evident related to the appointment of Mongolian lords to the occupied territories since 1265.

State management system of Khubilai Khan was inherited to his descendants and so reformed by generation to generation.

\section{MATERIALS}

There are several facts that foreign kings had great favor with Khubilai Khan and so his cooperation.

Khubilai Khan implemented below policies in countries he occupied. Herein:

- He introduced legal system based on justice.

- Occupied territories and states were in peace condition and secured from enemies and so with themselves.

- Various kinds of taxation system were demolished and they just paid only the state tax which is much lower than before.

- Taxation, custom fee and robberies percentage were decreased as gathered in one bureaucracy.

- Brand new system was introduced in envoy relation and relay stations which connect far long, hence visitors traveled through stations with no difficulties.

- Conflicts among various religions were concluded.

- Peace and friendship agreements were established between neighbor countries. 
Khubilai Khan was sent envoy to Wang of Vietnam in 1261 to establish friendship between Mongolian and Vietnam [4], therefore ambassador to Vietnam was appointed in 1262. King of Japan sent envoy with official letter in 1279 and 1283, and Cambodia was reunited in 1284.

Foreign affairs policy which is adopted by Khubilai Khan was inherited to his descendants and therefore developed in each time.

Friendship agreements were established as kings sent envoys to abroad such as Olzeitu Temur Khan's envoy to France in 1305, TugusTemur Khan's envoy to India in 1330 and Togoon Temur Khan's envoy in 1336 to Korea. Also paper bills transacted in commercial network with internal and external trade, hence it could established foreign cooperation with far away countries [5].

Policy and operations to strengthen economic management: Khubilai Khan implemented improvement of state economic management by developing taxation system, renting and custom policy. Main tools to gather wealth in the state treasure fund were tax, toll fee and custom fee quoted differently.

\section{Herein:}

- Income from subordinating territories

- Income from salt

- Income from sugar

- Income from fragrances and spices

- Tax on other goods

- Income from rice wine, coal and handicrafts

- Income from custom clearance and custom fee of the silk road

Khubilai Khan manufactured brand new weapon in 1272. In preparation of invasion to Japan, he was ordered to manufacture ships, therefore, 1000 ships from China, 150 ships from Korea in 1282 and 500 ships more in 1283 were supplied to army. Paper bills transacted into trade as silver rate depreciation took place. At that time, one cow equals twenty 744 gm silver and one horse equals 1116 gm silver.

State budget outcome was 2 times higher than its income during Yuan Dynasty period of Khubilai. There were such iron factories, some with over 1000 workers. Even in Kharakhorum, there were industries of jars, vases, carpentry, iron casting, tracks, wheat and all kinds of weapon.

\section{A. Social management policy and its operation}

By the order of Khubilai Khan, pensions were subsidized to poor people, orphans and widows in 1264 and national army service system was wholly changed in 1265. Impressment was due to 1 man from 2-3 family members, 2 men from 4-5 family members and 3 men from 6-7 family members. Population census was held in 1270 and in 1290.

In 1298 , the order was declared to subsidize pension to family of died soldier in battle.

During the period of Gamalla /grandson of Khubilai/, Kharakhorum city centered Mongolia was in tough situation as its population and in its finance. Therefore, OlzeituTemur Khan tried to overcome this situation by planting wheat and trading paper bills for several years. For example, Khenin Wang /Governor of Kharakhorum/ 200 thousand paper bills to poor people of Khongiraid which subordinates to Manjidai, 200 thousand paper bills to tribe of Wang Renchin, 90 thousand silks to tribe of Wang Buyanchir and princess Mishig, 100 thousand paper bills to subordinates of JononGamalla in 1295, 3 thousand sacks of cereals to tribe of Majirdai, 140 thousand packs of silk and 200 thousand sacks of cereals to army of Kharakhorum in 1297 and 380 thousand paper bills and 50 thousand sacks of cereal again to army of Kharakhorum in 1302. All this accounts were written in Yuan Dynasty script [6].

\section{B. Management relations and structure of relay stations of royalty}

Horse flock statistics was strictly confidential cause of its political and military strategy, therefore inspection was conducted with minister of livestock ministry each autumn and reported to king himself.

Khubilai Khan enacted new law in relay station's regulation in 1263 and in 1280, hence implemented the policy which is only allowed military lords to pass through stations in Mongolian territory and it was limited to other people to travel through the area of relay station.

Many relay stations were created which are branched out of Kharakhorum city. In Yuan Dynasty, stations were categorized such as oxcart, horse cart, carriage cart, on foot, dog sled. Particularly, during the period of 1263 , horse relay stations were 299 , oxcart stations were 2, carriage cart stations were 35 , on foot stations were 11 and dog sled stations were 15. Total amount of horses in stationswas 44300, carts were 3937 , ships 5921, ox 6900 , carriage carts 200 , donkeys 6000 , sheep 1150 , dogs 3000 , relay coachmen 3000[7]. 


\section{RESULTS}

Management methods of the Great Khans: Khubilai Khan reigned for 34 years, OljeituTemur Khan for 12 years, AyurbaribadhBuyantu Khan for 9 years, SidhabalaGegeen Khan, YesunTemur Khan and KhaisanKhulugKhaan for 4 years each, TegusTemur Khan for 3 years and TogoonTemur Khan reigned for 35 years.

Khubilai raised upon internal conflict between tribes besides envying enemies from abroad and all this life cruel disciplined him and to his ideology and leadership intelligence [8-10].

His ability, relation, infection were main characters to succeed for leader's position of the Great Yuan Dynasty. Hence, the main basic principle of relations was "To respect for fair relation".

- He has gained the ability to be aware on his failures and weakness by learning from his ancestors.

- In order to achieve his goal, he learned for the wise tactics that is to cooperate with enemy by appeasing previous fury.

- He had an ability to learn from other's failure.

- Also he has managed the skills to analyze even from his enemy's words.

Khubilai Khan was strict on his management technique based on external and internal solidarity.

He was the trailblazer and founder of democratic leadership as he gained distinctive methods of management. The loyal and honest manner was most important habit for him. He hatred twofaced people. He always observed and instructed his subordinates that prudery could cause trust break and there found many facts that he was strict on his principles [11-13].

Reward results continued in long period with good outcome and it was his significant method of his motivation, reward system and management network. His manners such as affecting people, showing rightness and his own relation was helped him greatly to lead the great empire. His exemplary manner was noticed a lot during the great assembly of state.

Management features:

- He developed the policy of his ancestors, Chinggis and Ugudey Khan, which was to pin his own city more than other foreign cities.
- He was self-disciplined to knowledge and literacy. Moreover, he prospered Yuan Dynasty as exemplary cultural empire in world.

- His natural mood was to respect human consciousness more than the treasures.

- He was innovator and management skilled person.

- Since his enthronement, he made great effort for state affairs.

- He was right decision maker to right situation.

- He was a great leader who makes his team with careful measure.

- He has shown that leaders must be innovators not observer and hence, he has organized a lot of novel works.

He was exemplary of leaders that leaders must have his own team and own ranks. Khubilai was shown the way of respect by giving chances to people in their own accord but not forcing them to give their efforts.

\section{CONCLUSION}

Khubilai Khaan: He detailed the organizational network by consisting of executive authority structure in state management system of Yuan Dynasty. He was a founder of political science and established science academy at that time. He could improve the foreign relations on cooperation by making friendship agreement with neighbor countries.

Khubilai Khan made the people with a steady lifestyle understand that Khans of the Great Yuan Empire respected and admired art, intelligence and culture of Mongolia, and protected and passed them to his descendants.

In the Great Yuan Dynasty, Great Kkans creatively followed the teachings inherited from the Mongolian Empire, Chinggis Khan's and other Great Khans's Empires to manage economy and businesses.

It has significant importance to research more on heritage of economic and management skills of the Great Yuan Dynasty and Khubilai Khan himself.

\section{REFERENCES}

[1] Dalai. Ch. (1992). Mongolian history, Yuan Dynasty (12601388), 3, UB.

[2] HamtiinButeel. (1967). BNMAU-iin tuuh, 2, UB.

[3] HamtiinButeel. (1990), Yuan Ulsiin Sudar,: UNS, pp. 10-32

[4] Sagan Setsen. (1960). ErdeniinTovch,: UB. 
[5] Namjim.T. (2000). Mongoliin Aj Ahui, Ediin zasag, 1, UB

[6] Vaanchig. (2005). Yuan ulsiin oron sudlaliin tuuhiin asuudal: Dissertation of doctoral degree, UB. pp.115-221

[7] Baljinnyam.B. (2005). Mongoliin burentuuhiin tovchoon.: First Edition, UB.

[8] Sagan Setsen. (1960). Erdeniintovch.: UB.

[9] History of Yuan Dai. (1987). Translation of Duudan, Saran, Ulzii, Sodom, Beijing.

[10] VanMandaa. (1999). Encyclopedia on Mongolian history, Inner Mongolia.

[11] Sukhbaatar.G. (2000). Mongoliin ertnii tuuh sudlal, 1. UB.

[12] Sukhbaatar.G. (1991). Mongolchuudiin ertnii uvug. Dissertation on historical doctoral degree: UB.

[13] HamtiinButeel. (2011). 108 versions of Mongolian science, Management skills, 35, UB. 